\title{
Internet Banking Adoption in South Africa: The Mediating Role of Consumer Readiness
}

\author{
Aguidissou O. C., Richard, Shambare, Rugimbana, R. \\ Tshwane University of Technology, South Africa \\ Omerich@yahoo.fr*,rshambare@gmail.com, RugimbanaR@tut.ac.za
}

\begin{abstract}
The recent rapid development of Internet banking (IB) around the world is not without certain challenges. For instance while a majority of banking SSTs (Self Service Technologies, e.g. ATMs and debit cards) have been well received by the South African market, consumers seem sceptical towards Internet banking. This paper seeks to test various conceptual frameworks of consumer adoption patterns of IB with the view of a framework with the greatest explanatory power for the South African market. To achieve the stated objective of a framework for IB adoption in South Africa, this paper suggests an approach not yet undertaken, according to the literature review conducted, within the South African retail banking industry investigating a comparison of the predictive efficacy of two common groupings of variables most cited in the consumer behaviour literature as important determinants of adoptive behaviour in SSTs. These are: perceptions of innovation characteristics and consumer readiness (CR) variables. Therefore, the primary objective of this article is the consideration of this gap within the body of knowledge around South African consumers' IB adoption behaviour. Through a descriptive quantitative analysis of 1516 large sample size, innovation characteristics as consumer's perceptions (complexity, perceived risk notably) or views (endogenous variables) were found with greatest predictive power over IB adoption, in the South African consumer market context. This finding is therefore for marketers (particularly in South Africa) a set of useful tools that can be relevant to promote the adoption of IB.
\end{abstract}

Keywords: Internet banking, Consumer choice behaviour, Innovation characteristics, Consumer readiness, South Africa

\section{Introduction}

In the last two to three decades, the South African banking industry has undergone significant reforms. The current state of retail banking in the country has been largely shaped by the on-going progressive deregulation of the financial services sector that began in the early 1990s (Falkena, Bamber, Llewellin and Store, 2001; Shambare, 2012). According to Falkena et al. (2001:80), the global trend of banking deregulation reached South Africa in the early 1990s; resulting in the removal of several previously-imposed restrictions and monopolies. For instance, financial institutions were no longer required to specialise in only one product line, meaning that insurance companies could say also offer banking services, which naturally increased competitive pressure in the industry. To maintain market share, banking institutions turned to innovations such as electronic banking systems and the rapid diffusion of technology-based product distribution channels (Falkena, Bamber, Llewellin and Store, 2001:390). Numerous SSTs were introduced in this period, such as IB in 1996 and cell phone banking in 2000 (Nel, 2013:45). While a majority of banking SSTs (e.g. ATMs and debit cards) have been well received by the South African market, consumers seem sceptical towards IB (Maduku, 2013:78). World Wide Worx (2013) found that IB remains the least adopted SST within the South African retail banking market. Consequently, there have been increasing efforts to encourage consumer patronage of IB (Maduku, 2013:94). In the quest to increase IB usage, financial institutions have, however, experienced challenges in formulating effective marketing strategies. There seems to be a general lack of marketing intelligence and in particular, limited knowledge on the diffusion and adoption patterns of the Internet and IB (Sabi, 2014:17). Overall, within developing countries, including South Africa, there has been a lack of academic research in the area of IB adoption (Maduku, 2013:76; Shambare, 2012:79). Thus, without the guidance of sound scientific research, financial institutions will experience difficulties in developing strategy to shift consumer behaviour towards IB adoption. Therefore, the primary objective of this article is the consideration of this gap within the body of knowledge around South African consumers' IB adoption behaviour. Against this background, this study seeks to test various conceptual frameworks of consumer adoption patterns of IB with a view to a framework with the greatest explanatory power for the South African market. The remaining part of this paper is as follows: Discussion on IB in South Africa as following section. Then, IB adoption framework is presented. Further the methodology and findings sections is made followed 
with results and discussion on summary findings, managerial implications, limitations and recommendations regarding future research.

\section{Literature Review}

Internet banking in South Africa: Since the early 1990s, the global trend towards deregulation, the rise of global financial services conglomerates, rapid technological developments and South Africa's reintroduction into the global economy contributed to the reshaping of the South African financial sector (Falkena et al., 2001:80). Today, all South African banks together with the 'big four' (ABSA, FNB, Standard Bank and Nedbank) provide e-banking services (Redlinghuis \& Rensleigh, 2010:2). According to World Wide Worx (2013), South Africa's IB user rate is still remarkably low at only about 23 per cent. IB, similarly to e-banking uses the Internet to access bank accounts and perform various functions as inter account-transfers, thirdparty payments and checking balances. Internet banking as defined by Yiu, Grant and Edgar (2007:337), is the delivery of banking services to customers through the Internet network. Consequently, it is a process which allows a consumer to perform banking functions online. In South Africa particularly, very little research has been conducted in terms of enhancing marketers' knowledge of consumers' decisions to adopt (or reject) banking SSTs. Therefore, conducting further research on predictors of internet banking (IB) adoption is imperative. Moreover, the approach taken by this study will contribute new knowledge within the consumer behaviour, internet banking adoption and consumer perception towards use of technology. To achieve the stated objective, the study developed a framework for innovation characteristics and consumer readiness, predictive power over internet banking adoption in South Africa.

Internet banking adoption framework: Rogers's (1962) IDT explains how over time, an idea or product gains momentum and diffuses through specific population. Rogers (1995:16) enriched the same idea by arguing that potential users make decisions to adopt or reject an innovation based on beliefs that they form about the innovation. It includes five significant characteristics: compatibility, relative advantage, complexity, observability and trialability (Rogers, 1995:265-266). But other characteristics, mainly perceived risk, have been also added to those listed as reported by Kassangoye, De Jager and Rugimbana (2013:378). This paper is focused on IB, an SST adoption case, which involves knowledge on consumer readiness, attitudes or behaviours which are developed. Meuter, Bitner, Ostrom and Brown (2005:64), stated that CR is the "state in which consumers are prepared and likely to use an innovation for the first time". Consequently, consumer readiness variables form part of the study framework. Meuter et al. (2005:62) argue that "there are certain innovation characteristics or individual differences that vary in direction and significance across different contexts". Therefore, they suggest that the way to clarify the inconsistencies is through the use of mediating variables to explain relationships between variables. A consumer readiness variable is introduced to mediate between the innovation characteristics variables and the behaviour of trial (of the innovation) as the first step of consumer adoption. In order to identify the predictive power of innovation characteristics and consumer readiness, this paper draws on Meuter et al. (2005) model. The innovations characteristics are first of all defined followed by consumer readiness.

Relative advantage: Relative advantage is defined as, "the degree to which an innovation is perceived as being better than the idea it supersedes" (Rogers, 1995:212; 2003:15).

Compatibility: Compatibility refers to the extent to which individuals perceive that new products or services have no conflict with their needs, beliefs, values and experiences (Rogers, 1995:224; 2003:15-16). According to Rogers (2003:240), compatibility is defined as "the degree to which an innovation is perceived as consistent with the existing values, past experiences, and the needs of potential".

Trialability: Trialability is defined as, "the degree to which an innovation may be experimented within a limited basis, which allows individuals to test drive an innovation before it is being adopted" (Rogers, 1995:243; 2003:16).

Observability: Observability, defined as "the degree to which the results of an innovation are visible to others" (Rogers, 1983:244; 2003:15-16). The degree to which an innovation is perceived as being difficult to understand and/or to use, is defined as complexity of an innovation (Rogers, 1995:242; 2003:16)

Complexity Perceived risk: "Risk" refers to a hazard that involves a cost (Paulino, 2011:5). Perceived risk originated from the motivation of consumers to process information. It is also about Perceived risk is known 
as the negative attribute, and perceived benefit, the positive one. Consumer readiness includes role clarity, motivation (intrinsic and extrinsic) and ability. A customer's behaviour towards a product depends on his readiness to use it. People who lack knowledge, understanding, motivation or skill on Internet banking, may never become a potential user of this technological banking innovation product. Meuter et al. (2005:76) findings show that consumer readiness variables have greater influence on consumer adoption of self-service technologies (SST) than the other variables.

Role clarity: Role clarity is about customers' knowledge and comprehension of the kind of participation which needs to take place. In true, customers' knowledge on what to do and performance expectations have a greater tendency to do things that are needed.

Motivation: Motivation is the "forerunner of any tangible achievement in life" (Adeboye, 2015). Oyserman and Sorrenson (2009:253), by linking identity to motivation, stated that "identity-based motivation results in the readiness to take action, even when the action is not beneficial to the participant or is unlikely to have been chosen outside of the specific context."

Ability: In the views of Meuter et al. (2005:64), ability is about the extent to which the consumer possesses the necessary skills and needed equipment to perform a particular task (or to use new innovations).

\section{Figure 1: IB adoption proposed conceptual model}

Antecedents Predictors $\quad$ Mediating Variables $\quad$ Adoption Process

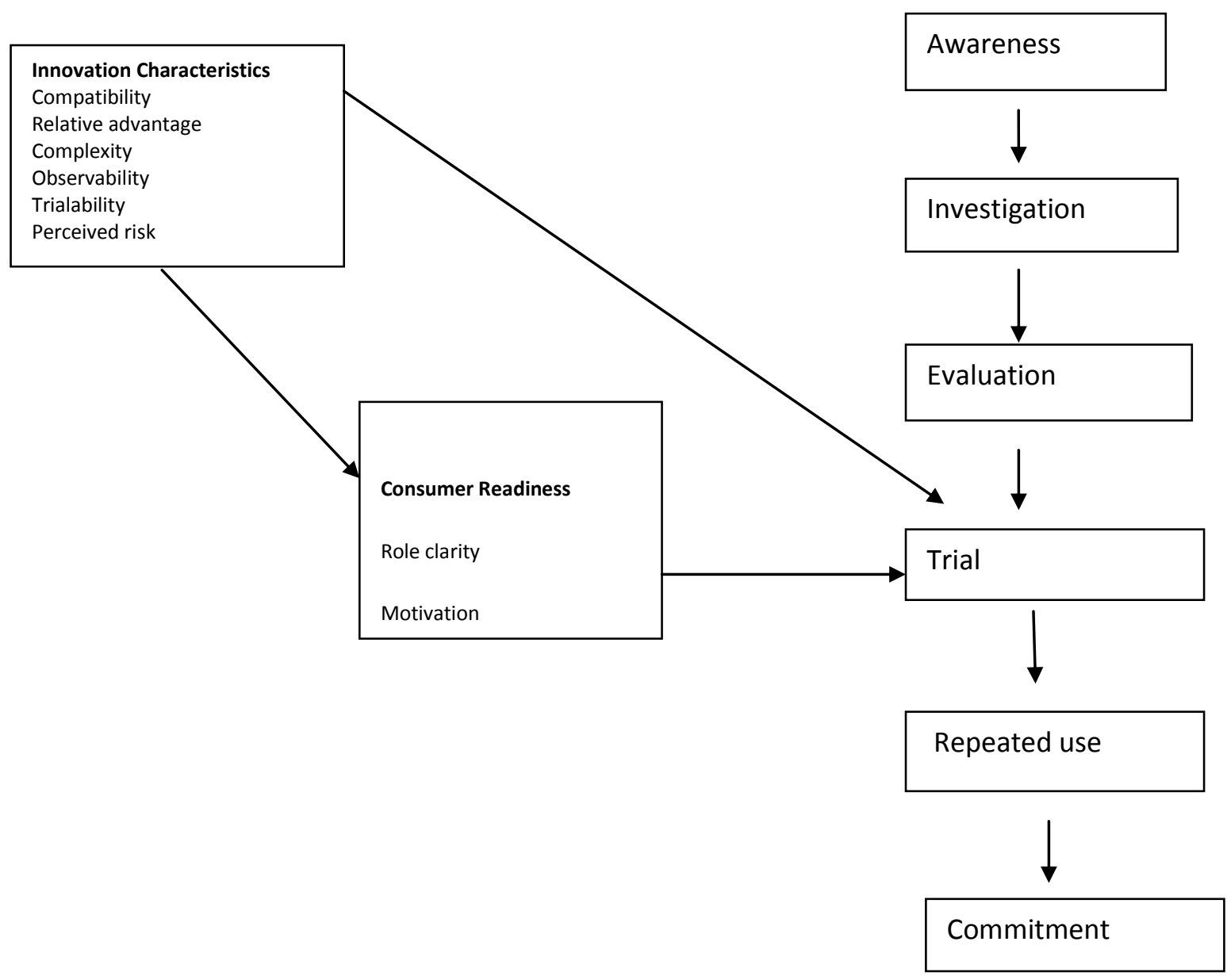

Source: Adapted from Meuter et al. (2005:63)

In conclusion, two sets of variables namely innovation characteristics and consumer readiness variables, are combined together in this article model to aim for credible and accurate research findings results. 
Research questions and hypotheses: The following research question was formulated: In South Africa, what is the predictive power of exogenous and endogenous variables on Internet banking adoption among consumers?

Consequently the research hypotheses are formulated as follows and offered basis for data collection and data analysis:

$\mathrm{H}_{1}$ : Role clarity mediates the relationship between:

Innovation characteristics variables and trial

$\mathrm{H}_{2}$ : Extrinsic motivation mediates the relationship between:

Innovation characteristics variables and trial

$\mathrm{H}_{3}$ : Intrinsic motivation mediates the relationship between:

Innovation characteristics variables and trial

$\mathrm{H}_{4}$ : Ability mediates the relationship between:

Innovation characteristics variables and trial

$\mathrm{H}_{5}$ : The consumer readiness variables are better predictors of trial than:

Innovation characteristics variables

\section{Methodology}

A descriptive single cross-sectional design according to Malhotra (2010:108) is the applied methodology for this study. From self-completion structured questionnaire respondents, data was collected. For data analysis, the analysis of statistics was made in line with the collected quantitative data.

Sample: The quantitative method of empirical inquiry, using the descriptive survey research design, was employed for investigation related to the present study (Malhotra, 2010:108). Collecting data from respondents took place by using self-completion structured questionnaires with a 'drop and pick' collection technique method. This research is one with tested existing theories which "explains the precise relationships between variables" according to Perry (2002:26); research design therefore is an explanatory (causal) in nature as reported by Nel (2013:78-79). The sample size of 1516 which largely surpassed the recommended minimum of 590 participants recommended by Pallant (2010), and 385 according to Raosoft (2016) was largely sufficient and able to generalise the findings of the study for a total of 7000000 Gauteng's province adults population. A stratified sampling technique was used to ensure the selection of a sample whose characteristics are in line with the population of the Gauteng Province. The measured constructs influencing choice behaviour factors known as 'real-life' phenomena (Healy and Perry, 2000:120) in past research, were identified and tested (Berndt, Saunders and Petzer, 2010; Black, Lockett, Winkhlofer and Ennew, 2001; Laukkanen, Sinkkonen, Kivijarvi and Laukkanen, 2007; Parasuraman, 2000; Rugimbana, 1998; Shambare, 2012). Except for studies such as Mallat (2007), Szmigin and Bourne (1999) that utilized qualitative approach, quantitative methods was used in the vast majority of studies to measure IB adoption. It is for this reason that quantitative techniques are used in this study. A large sample size of $1516(70.51 \%)$ students questionnaires respondents was completed and used during the present study compares to the total of 2150 , distributed for the present investigation. It was desirable to use a homogenous sample (i.e., students) as they are a homogeneous sample. Using homogenous samples, according to Calder et al. (1981:200) is preferred for theory testing.

Questionnaire adaptation: The instrument of data collection is about questions measuring diverse aspects in relation to respondents' demographic characteristics, banking profiles and the parameters. Table 1 presents the structure and questionnaire rationality. Testing the predictive power of antecedent predictor variables (innovation characteristics) and mediating predictor variables namely consumer readiness variables, in order to predict consumer choice behaviour, is the present study's objective. In the conceptual model which is proposed in the area of Internet banking choice, three main elements are highlighted: Innovation characteristics, consumer readiness and adoption, operationalised by trial representing those parameters. A Likert scale ( 1 = Strongly Disagree; $5=$ Strongly Agree) and structured questions were utilised. The first two variables are continuous and were measured by using a 5 -point Likert scale anchored at $1=$ Strongly Disagree and 5 = Strongly Agree. As measured by trial, adoption is a discrete (nominal) value. In sum, the questionnaire was eight pages long, comprising three parts: the respondents' banking profile, measurement scales and demographic sections (Table 1).For 2150 questionnaires collected from 
respondents, 1516 responses were used for the present study as total sample size for the survey that was conducted with $45,80 \%$ as male and $54,20 \%$ as female; $69,90 \%$ of these students age is between 21 -30 years with $93.70 \%$ as undergraduate. $78,70 \%$ among them are with monthly income less than 5000 (ZAR), 62,10\% as full time students. Table 2 below illustrated participant demographic characteristic. Different statistical analyses were performed using SPSS v. 23 (Field, 2009).

Table 1: Data collection instrument format

\begin{tabular}{|c|c|c|c|}
\hline Section & Section summary & Scale development & Rationale \\
\hline$A$ & $\begin{array}{l}\text { Respondents' banking profile: } \\
\text { Information in the banking profile area. } \\
\text { This encompasses the types of bank } \\
\text { accounts utilised and also how often } \\
\text { these were utilised. }\end{array}$ & $\begin{array}{l}\text { Brown, Cajee Davies } \\
\text { and Stroebel (2003); } \\
\text { Rugimbana (1998) }\end{array}$ & $\begin{array}{lr}\begin{array}{l}\text { To } \\
\text { respondents' } \\
\text { patterns }\end{array} & \text { determine } \\
\end{array}$ \\
\hline$B$ & $\begin{array}{l}\text { Antecedent predictors' scales: } \\
\text { Measure independent and mediating } \\
\text { variables. }\end{array}$ & $\begin{array}{l}\text { Meuter et al. (2005); } \\
\text { Parasuraman (2000); } \\
\text { Rogers (1995) }\end{array}$ & $\begin{array}{l}\text { Measuring } \\
\text { perceptions and CR }\end{array}$ \\
\hline C & $\begin{array}{l}\text { Respondents' } \\
\text { characteristics: } \\
\text { Demographics }\end{array}$ & $\begin{array}{l}\text { Developed for this } \\
\text { research from the } \\
\text { literature review }\end{array}$ & $\begin{array}{l}\text { To describe demographic } \\
\text { characteristics of the } \\
\text { sample }\end{array}$ \\
\hline
\end{tabular}

Source: Researcher's own construct

Data analysis: As a result of the quantitative data collected, different statistical analyses were done. SPSS v. 23 was used to perform analysis as followed (Field, 2009):

- Descriptive statistics for samples' demography description and banking-related Profiles (Daniel \& Terrel, 1995:42).

- Chi-square tests for association identification among variables (Field, 2009:269).

- Reliability analysis - through Cronbach's alpha, the internal consistency (reliability) related to measurement scales is assessed (Emory \& Cooper, 1991:187).

- Factor analysis -variables' reduction to latent variables smaller groups, as well as validity tests (Field, 2009:629; Malhotra \& Birks, 2007:125).

- Multiple regression and logistic regression - for the proposed model and hypotheses testing (Hair et al., 1998:90).

\section{Results}

Table 2: Demographic profile

\begin{tabular}{lll}
\hline \multicolumn{2}{l}{ Demographic characteristic } & $\begin{array}{l}\text { South Africa } \\
\text { (\%) }\end{array}$ \\
\hline Gender & Male & 45.80 \\
& Female & 54.20 \\
Age & <20 years & 21.80 \\
& 21 - 30 years & 69.90 \\
& 31+ years & 8.30 \\
Study level & & \\
& Undergraduate & 93.70 \\
Monthly income & Postgraduate & 6.30 \\
& & \\
& <R5 000 & 78.70 \\
& R5 001 - R10 000 & 11.30 \\
& R10 001 - R15 000 & 2.90 \\
& R15 001 + & 7.10
\end{tabular}




\begin{tabular}{lll} 
Source of income & Employed full-time & 6.50 \\
& Employed part-time & 5.30 \\
Self employed & 2.70 \\
& Full-time student & 62.10 \\
& Part-time student & 12.90 \\
Unemployed/retired & 10.50 \\
\hline
\end{tabular}

Source: Own construct

In total, 2150 questionnaires were distributed to respondents to the investigation. As result, only $1516(70.51 \%)$ completed questionnaires were collected and used for the present study. The male respondent participant rate of $45.8 \%$ was smaller than their female counterparts which is $54.20 \%$ as described on Table 2. Significantly, the proportion of $69.9 \%$ is representative of the age group 21 to 30 years. $21.80 \%$ and $8.30 \%$ per cent represent respectively respondent age group for less than 20 years and more than 30 years according to present investigation (Table 2). Table 2 depicted also that the biggest percentage (78.7\%) of participants are undergraduate with an income of not more than R5 000 per month, while the remaining of $6.30 \%$ are postgraduate. As presented by Table 2, only $7.10 \%$ of respondent earn more than R15 000 per month, while $11.30 \%$ monthly earning, is not more than R10 000 . The fewest $2.90 \%$ respondent monthly earning is between R10 001 and R15 000. Full time student with $62.10 \%$, constitutes the highest rate of this present research participant, while the lowest rate of $2.70 \%$ refers to self-employed student participant. The remaining, $6.50 \%, 5.30 \%, 12.90 \%$ and $10.50 \%$ are respectively full-time employed students, part-time employed students, part-time students and unemployed or retired as shown in Table 2. This provides the key demographic characteristics of the study sample.

Respondents' banking profile: Table $3.1 \mathrm{a}$ and table $3.1 \mathrm{~b}$ summarize banking profile.

Table 3.1a: Bank institutions use

\begin{tabular}{lll}
\hline Bank & Count & $\begin{array}{l}\text { Percentage } \\
\mathbf{( \% )}\end{array}$ \\
\hline Capitec & 558 & 30.05 \\
Standard Bank & 382 & 20.57 \\
FNB & 332 & 17.88 \\
ABSA & 315 & 16.96 \\
Nedbank & 190 & 10.23 \\
Do not have a bank account & 35 & 1.89 \\
Post Bank & 19 & 1.02 \\
Other banks & 7 & 0.38 \\
African Bank & 6 & 0.32 \\
Bidvest & 5 & 0.26 \\
Mercantile & 4 & 0.22 \\
Bank of Athens & 4 & 0.22 \\
\hline
\end{tabular}

Source: Own construct; $* \%$ based on total number of respondents

Table 3.1b: Extent of channel use (1=never; $6=$ daily)

\begin{tabular}{llll}
\hline Banking channel & Mean & Std Dev. & users \% \\
\hline Bank branch & 2.82 & 1.76 & 53.30 \\
EFTPoS & 2.77 & 1.82 & 50.20 \\
Cell phone banking & 2.77 & 1.82 & 50.20 \\
Bank App & 1.78 & 1.39 & 23.30 \\
Telephone & 1.78 & 1.38 & 23.20 \\
ATM & 1.58 & 1.27 & 16.10 \\
\hline
\end{tabular}

Source: Own construct 


\section{Scale Measurement}

Construct reliability: The measuring of the multi-item scales questionnaire reliability was done by using Cronbach's alpha (Mazzocchi, 2011; Bryman \& Cramer, 2001:71). Reliability is about multiple variables' measurements, accuracy, precision and consistency (Hair et al., 2010). Internal consistency as reliability is a commonly used measure to ascertain in a set of questions, how well items are positively inter-correlated. According to Field (2009:677), the setting of the minimum alpha standard practice threshold to consider, is 0.7 .

Table 4: Cronbach's alpha $(\alpha)$ for the subscales

\begin{tabular}{ll} 
Multi-item scale & Internet banking \\
& \\
\hline Relative advantage & .775 \\
Complexity & .798 \\
Observability & .827 \\
Compatibility & .854 \\
Trialability & .465 \\
Perceived Risk & .897 \\
Role Clarity & .764 \\
Ability & .700 \\
Extrinsic Motivation & .830 \\
Intrinsic Motivation & .882 \\
\hline
\end{tabular}

Source: Own construct; (Study sample) <.4 cut off

Table 5: Variables KMO / Barlett's test of sphericity values

\begin{tabular}{ll}
\hline $\begin{array}{l}\text { Multi-item KMO / Barlett's test } \\
\text { (p-values) }\end{array}$ & Internet banking \\
\hline Relative advantage & $.688(.109)$ \\
Complexity & $.710(.000)$ \\
Observability & $.693(.000)$ \\
Compatibility & $.850(.000)$ \\
Trialability & $.594(.008)$ \\
Perceived Risk & $.914(.000)$ \\
Role Clarity & $.658(.020)$ \\
Ability & $.711(.515)$ \\
Extrinsic Motivation & $.718(.000)$ \\
Intrinsic Motivation & $.878(.000)$ \\
\hline
\end{tabular}

Source: Own construct; Cut off point < 0.5 (Field, 2009:660)

Construct validity: As a result, the validity of the independent variables was determined employing factor analysis which is a multivariate statistical method characterised by three keys functions (Stewart, 1981). The first key function consists on reducing to smaller size variables, the number in case information analysis amount is maximised. The second one is by searching in case of data being too large, qualitative and quantitative data distinction. The last key function is about hypotheses testing relative to distinction numbers or undergoing data set. Specifically, Oblimin rotation with principal components analysis (PCA) was used not only for determining the items factors loading, but also for the inter correlation of factors themselves (Hair et al., 2010). Proceeding with PCA involved the use of Kaiser-Meyer-Olkin (KMO) for the measure of sampling adequacy (MSA) and the Sphericity Bartlett's test (Shiu, Hair, Bush and Ortinau, 2009). 
Table 6: PCA loadings of independent variable constructs

\begin{tabular}{|c|c|c|}
\hline \multicolumn{2}{|l|}{ Independent variable } & $\begin{array}{l}\text { Banking channel } \\
\text { Internet banking }\end{array}$ \\
\hline IDT $\left(X^{2}=1.702 ; p=.0192\right)$ & $\begin{array}{l}\text { Factors retained } \\
\% \text { variance }\end{array}$ & $\begin{array}{l}2 \\
61.296 \%\end{array}$ \\
\hline $\operatorname{CR}\left(X^{2}=10.205 ; p=.001\right)$ & $\begin{array}{l}\text { Factors retained } \\
\% \text { variance }\end{array}$ & $\begin{array}{l}1 \\
55.054 \%\end{array}$ \\
\hline
\end{tabular}

Source: Own construct

The KMO index range is from 0 to 1 . Value $0.90+$ is marvellous, while value $0.60+$ is mediocre and below .50 , unacceptable (Field; 2009:647). For this study, KMO index range is higher than 0.7, which is acceptable. Secondly, for proceeding with factor analysis as scientifically recommended, the statistical probability, proof of the existence of correlation matrix with significant correlations among variables, is generated by Bartlett's Test of Sphericity index ( $>0.6)$, which is viewed a minimum tolerance. Lastly, in all cases the Bartlett's Test yielded p-values $(p<0.05)$, which are significant and high. Overall, 10 components of items' total had Eigen values over Kaiser's criterion of 1 explain in combination more than $62.020 \%$ of the variance. Barlett's test of sphericity $\mathrm{X}^{2}(1516)=292449.950, \mathrm{p}<0.001$, indicating for PCA, that correlations between items were sufficiently large (Field, 2009:672). KMO index range for this study is 0.934 higher than 0.90, which is marvellous value. The factor structures, regarding both scales (IDT and CR) loaded in conformity to the theory content (Table 6).

Test of model and hypotheses: For the test related to IB trial, mediated effects could not be concluded between CR and both independent variables. For variable ability for instance, the effect on dependent variable according to Table 7 is not significant at all [coefficient $=-21.169 ;(p=.998)$ ]. The meaning of this fact is that no any independent variable is mediated by the factor ability. Additionally, though the other three mediating variables, role clarity, extrinsic motivation and intrinsic motivation respectively $[\mathrm{B}=-1.661 ; \mathrm{p}=$ $.000],[\mathrm{B}=-1.551 ; \mathrm{p}=.000]$ and $[\mathrm{B}=-1.259 ; p=.000]$ have effect on dependent variable, not all items of both independent variables are mediated by at least one mediating factor. Role clarity alone, among all four CR variables, mediated complexity, compatibility, trialability and perceived risk, but without effect on relative advantage. Overall, not all antecedent predictors of both independent variables that have direct effect on trial, were found mediated by at least one mediating factor. It was deducted therefore that CR doesn't mediate the independent variables (innovation characteristics) for IB product.

Table7: Results of tests of mediation: IB

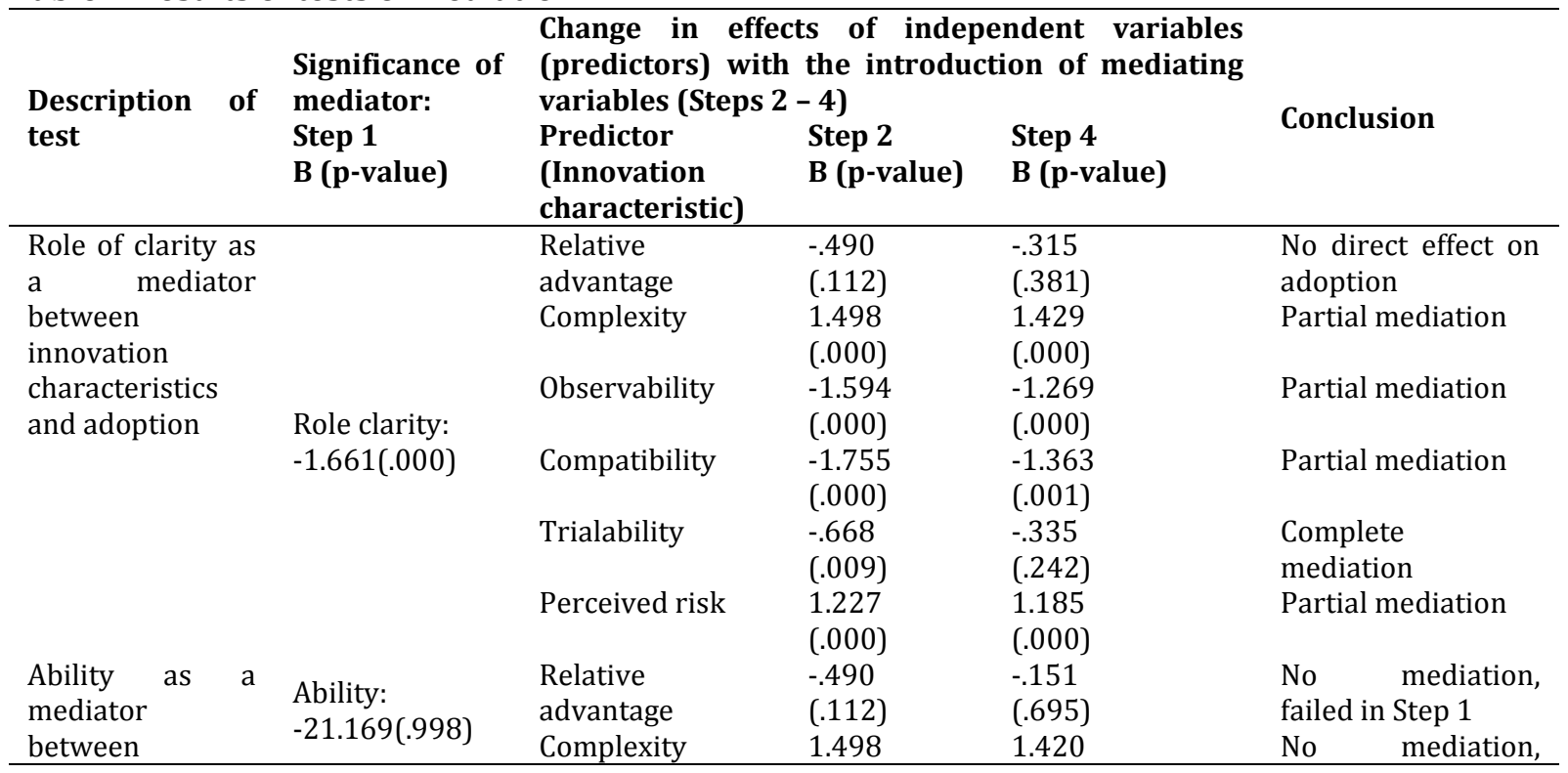




\begin{tabular}{|c|c|c|c|c|c|}
\hline \multirow{9}{*}{$\begin{array}{l}\text { innovation } \\
\text { characteristics } \\
\text { and adoption }\end{array}$} & & & $(.000)$ & $(.000)$ & failed in Step 1 \\
\hline & & \multirow{2}{*}{ Observability } & -1.594 & -1.168 & No mediation, \\
\hline & & & $(.000)$ & $(.008)$ & failed in Step 1 \\
\hline & & \multirow[t]{2}{*}{ Compatibility } & -1.755 & -.832 & No mediation, \\
\hline & & & $(.000)$ & $(.072)$ & failed in Step 1 \\
\hline & & \multirow[t]{2}{*}{ Trialability } & -.668 & -.120 & No mediation, \\
\hline & & & $(.009)$ & $(.721)$ & failed in Step 1 \\
\hline & & \multirow[t]{2}{*}{ Perceived risk } & 1.227 & 1.090 & No mediation, \\
\hline & & & $(.000)$ & $(.000)$ & failed in Step 1 \\
\hline \multirow{12}{*}{$\begin{array}{l}\text { Extrinsic } \\
\text { motivation as } \\
\text { mediator } \\
\text { between } \\
\text { innovation } \\
\text { characteristics } \\
\text { and adoption }\end{array}$} & \multirow{12}{*}{$\begin{array}{l}\text { Extrinsic } \\
\text { motivation: } \\
-1.551 \\
(.000)\end{array}$} & Relative & -.490 & -.125 & No direct effect on \\
\hline & & advantage & $(.112)$ & $(.726)$ & adoption \\
\hline & & Complexity & 1.498 & 1.510 & No mediation, \\
\hline & & & $(.000)$ & $(.000)$ & failed in Step 4 \\
\hline & & Observability & -1.594 & -1.444 & Partial mediation \\
\hline & & & $(.000)$ & $(.000)$ & \\
\hline & & Compatibility & -1.755 & -1.422 & Partial mediation \\
\hline & & & $(.000)$ & $(.002)$ & \\
\hline & & Trialability & -.668 & -.201 & Complete \\
\hline & & & $(.009)$ & $(.483)$ & mediation \\
\hline & & Perceived risk & 1.227 & 1.205 & Partial mediation \\
\hline & & & $(.000)$ & $(.000)$ & \\
\hline \multirow{12}{*}{$\begin{array}{l}\text { Intrinsic } \\
\text { motivation as } \\
\text { mediator } \\
\text { between } \\
\text { innovation } \\
\text { characteristics } \\
\text { and adoption }\end{array}$} & \multirow{12}{*}{$\begin{array}{l}\text { Intrinsic } \\
\text { motivation: } \\
-1.259(.000)\end{array}$} & Relative & -.490 & -.012 & mediation, \\
\hline & & advantage & $(.112)$ & $(.972)$ & failed in Step 4 \\
\hline & & Complexity & 1.498 & 1.492 & mediation, \\
\hline & & & $(.000)$ & $(.000)$ & failed in Step 3 \\
\hline & & Observability & -1.594 & -1.390 & Partial mediation \\
\hline & & & $(.000)$ & $(.000)$ & \\
\hline & & Compatibility & -1.755 & -1.166 & Partial mediation \\
\hline & & & $(.000)$ & $(.005)$ & \\
\hline & & Trialability & -.668 & -.396 & Complete \\
\hline & & & $(.009)$ & $(.160)$ & mediation \\
\hline & & Perceived risk & 1.227 & 1.275 & No mediation, \\
\hline & & & $(.000)$ & $(.000)$ & failed in Step 4 \\
\hline
\end{tabular}

Table 8: Hypotheses testing results

\begin{tabular}{ll}
\hline \multicolumn{1}{c}{ Hypotheses } & Supported \\
\hline H1: Role clarity mediates the relationship between: & supported \\
Innovation characteristic variables & \\
H2: Extrinsic motivation mediates the relationship between: & supported \\
Innovation characteristic variables & \\
H3: Intrinsic motivation mediates the relationship between: & supported \\
Innovation characteristic variables and trial & \\
H4: Ability mediates the relationship between & not supported \\
Innovation characteristic variables & \\
$\begin{array}{l}\text { H5: The consumer readiness variables are better predictors of trial than: } \\
\text { Innovation characteristic variables }\end{array}$ & not supported \\
\hline
\end{tabular}

Source: Own construct

Past findings demonstrated that complexity, perceived risk and role clarity are related to adoption (Ngandu, 2012; Shambare, 2012; $\mathrm{Wu}, 2005)$ which also is confirmed in this paper. Ngandu (2012), on how factors prompting electronic banking adoption; Shambare (2012) on comparing the role of consumer perception and personality variables in predicting consumer preference for remote banking services; Wu (2005) on investigating attitudes of retails banking over customer in South Africa. Similarly to present study findings, all these cited authors, earlier underlined by one way or other the remarkable influential role of variables 
complexity, perceived risk and role clarity on consumers' decision over banking products' adoption in South Africa. As previously defined, complexity is about degree to which an innovation is perceived as being difficult to understand and/or to use, is defined as complexity of an innovation (Rogers, 1995:242; 2003:16). Complexity as well as perceived risk are negatively related to innovation adoption (Black et al., 2001:392). Except relative advantage, innovations' complexity as concluded Black et al. (2001:392) was more highly related to their adoption rate than any other innovation characteristics.

Discussion: Meuter et al. (2005) conducted similar study among USA consumers regarding banking Self Service Technologies in general and underlined consumer readiness variables predictive power over innovation characteristics variables. By contradiction with Meuter et al. (2005) findings, this paper "In South Africa, consumer's perceptions (endogenous variables) like complexity and perceived risks variables notably provide better explanatory power in describing IB as SST adoption" (Rogers, 1995; Ngandu, 2012:117; Shambare, 2012:178). Innovation characteristics outperform consumer readiness predictors for classification accuracy compared to CR. Two variables among the six innovation characteristics, namely complexity and perceived risk and one of consumer readiness (role clarity), were highly significant $(p<0.01)$. Complexity with the strongest Wald score is the biggest contributor within the predictor. The present study, by conducting the related investigation, established the fact that perceptions variables are irrefutably vital for IB adoption as other SSTs, relevant antecedent predictors of consumer choice behaviour. In other words, as employed in studies like IDT referring Rogers (1962; 1983; 1995), TRI Parasuranam (2000), Meuter et al. (2005) and stressed by Kelly, Lawlor and Mulvey (2010) and Dhurup, Surujlal and Redda (2014), the related study's conceptual frameworks are not only usable in a country like South Africa, but can be suggested for use by the body of knowledge for wider applicability.

The present paper's survey findings are proof that South Africa's country-specific conditions can efficiently be explained within research work, and therefore must be seen as a useful and encouraging tool for both bank managers and researchers. Obviously, research needs to be extended to other SSTs with regard to the present study framework. Studies which focused only on one common grouping of variables as the determinant of adoption behaviour, involved good empirical research (Akinci, AksoyandAtilgan , 2004:212; Cai Yang and Cude, 2008:151; Hoppe et al., 2001:1; Maduku, 2013:76) that is applied to IB, mostly within a South African context. But there are some phenomena that could not be explained, due to inconsistencies on some findings as stated by Meuter et al. (2005:62). This is the motive of this paper, for better explanation of phenomena one should consider two sets of variables simultaneously. As stated by Meuter et al. (2005:62), "to date, the question of why innovation characteristics influence adoption behaviour has been left largely unexplored". Though encouraging, the present study results leave unexplored fields for better explanation phenomena which are still to be conquered. That is why the need for future research is still pending. This research was conducted using a university student sample, which according to Calder, Phillips and Tybout (1981:200), is a homogeneous sample as indicated. But a wider consumer range could have been associated; this is seen as a limitation through the relatively validated scales of the large sample size $(n=1516)$. The theory model applied referred exclusively to innovation characteristics, whereas other theories such as TRA, TPB and TAM could also have been employed. Finally, the study is limited in this investigation by only considering the Gauteng Province, while investigation could have covered the whole country.

\section{Conclusion}

The attempt to provide an answer to the above objective concluded first of all that all two mentioned variables significantly predict IB adoption in South Africa. Secondary results also brought evidence for the fact that consumer readiness was found with mediating effects between explanatory variables (perceptions) and trial. Finally, comparing the predictive power of both variables as in the objective, perceptions (endogenous variables) were found in South Africa with greater predicting power over IB consumer choice behaviour and decision-making (Ngandu, 2012:117; Shambare, 2012:178; Wu, 2005:131-132). Future studies are encouraged to cover other provinces beside Gauteng in order to compare the investigations results with the present one. By doing so, bank marketers and the body of knowledge can really be provided with factors influencing the nation's IB consumer choice behaviour and decision-making. Factors predicting other SSTs like ATM, cell phone banking and telephone banking also using Meuter et al. (2005), can also be explored in order to give useful tools to bank decision-makers and also filling the related research gap within the domain. 


\section{References}

Adeboye, E. A. (2015). Open Heavens. A guide to close fellowship with God, 15(2015).

Akinci, S., Aksoy, S. \& Atilgan, E. (2004). Adoption of Internet banking among sophisticated consumer segments in an advanced developing country. International Journal of Bank Marketing, 22(3), 212232.

Black, N. J., Lockett, A., Winkhlofer, H. \& Ennew, C. (2001). The adoption of Internet financial Services. A qualitative study. International journal of Retail \& Distribution Management, 29(8), 390-398

Brown, I., Cajee, Z., Davies, D. \& Stroebel, S. (2003). Cell phone banking; Predictor of adoption in SA. An explanatory study. International Journal of Information Management, 23, 381-394.

Bryman, A. \& Cramer, D. (2001). Quantitative Data Analysis with SPSS release 10 for windows: A guide for Social Scientists, London: Routledge.

Cai, Y., Yang, Y. \& Cude, B. (2008). Inconsistencies in U.S consumers' attitudes toward and use of electronic banking: an empirical investigation. Journal of leisure Research, 25(3), 263-280.

Calder, B. J., Phillips, L. W. \& Tybout, A. M. (1981). Designing Research for Application. Journal of Consumer Research, 8(2), 197-207.

Daniel, W. W. \& Terrel, J. C. (1995). Business statistics: For management and economics. 7th ed. Boston: Houghton Mifflin.

Dhurup, M. Surujlal, J. \& Redda, E. (2014). Customer perceptions of online banking servicequality. Mediterranean Journal of Social Sciences, 2(1).

Emory, C. W. \& Cooper, D. R. (1991). Business Research methods. $4^{\text {th }}$ ed. Homewood, IL: Irwin.

Falkena, H., Bamber, R., Liewellyn, \& Store, T. (2001). Financial Regulations in South Africa; SA. Financial Sector Forum.

Field, A. (2009). Discovering Statistics Using SPSS, $3^{\text {rd }}$ Edition. Thousand Oaks, CA, Sage.

Hair, J. F., Black, W. C., Babin, B. J., Anderson, R. E. \& Tatham, R. L. (1998). Multivariate data analysis. $5^{\text {th }}$ ed. Upper Saddle River, N J. Prentice Hall.

Healy, M. \& Perry, C. (2000). Comprehensive Criteria to judge Validity and Reliability of Qualitative Research within the Realism Paradigm. Qualitative Market Research: An International Journal, 3(3), 118-126.

Hoppe, R., Newmann, P. \& Mugera, P. (2001). Factors affecting the adoption of Internet Banking in SA. A comparative study. Department of Information Study: University of Cape Town.

Kassangoye, W., Jager, J. W. \& Rugimbana, R. (2013). Internet adoption and usage patterns among students in selected South African Universities. Journal of Economics and Behavioral Studies, 5(6), 376-384.

Kelly, P., Lawlor, J. \& Mulvey, M. (2010). A review of key factors affecting the adoption of SST in tourism. THRIC Conference. Shannon.

Laukkanen, T., Sinkkonen, S., Kivijarvi, M. \& Laukkanen, P. (2007). How personal values determine consumer resistance to mobile banking. International Business Academics Consortium (IBACNET).

Maduku, D. K. (2013). Predicting retail banking customers' attitude towards Internet Banking services in South Africa. Southern Africa Business Review Journal, 17(3), 76-100.

Malhotra, N. (2010). Marketing Research: An Applied Orientation, 6th Edition. Upper Saddle River, NJ Pearson.

Malhotra, N. K. \& Birks, D. F. (2007). Marketing research. An applied approach. $3^{\text {rd }}$ European ed. Harlow: Pearson Education.

Mallat, N. (2007). Exploring consumer adoption of mobile payments - a qualitative study. Journal of Strategic Information Systems, 16, 413-432.

Mazzocchi, M. (2011). Statistics for Marketing and Consumer Research. London, Consumer Buying Behavior in Financial Services: an overview. International Journal of Bank Marketing, 10(5), 4-12. Sage.

Meuter, M. L., Bitner, M. J., Ostrom, A. L. \& Brown, S. W. (2005). Choosing among alternative service delivery modes: An investigation of customer trial of self-service technologies. The Journal of Marketing, 69, 61-83.

Ngandu, T. B. (2012). Perception of electronic banking among Congolese clients of South African Banks in the Greater Durban area. Master of Technology Marketing. Durban University of Technology.

Nel, J. (2013). Cell phone banking adoption and continuance of use in an Internet banking context: A study of consumers' cross-channel cognitive evaluations. Stellenbosch University.

Oyserman, D. \& Sorrenson, N. (2009). Understanding cultural syndrome effects on what and how we think. A situated cognition model in R. Wyer, Y. -y. Hong. and C. -y Chiu Editions, Understanding culture. Theory, Research and Application :25-52. NY; Psychology, press. 
Pallant, J. (2010). SPSS Survival Manual: A step by step guide to data analysis using SPSS, 4th Edition. Berkshire, UK, McGraw-Hill.

Parasuraman, A. (2000). Technology Readiness Index (TRI). A multiple item scale to measure readiness to embrace new technologies. Journal of Service Research, 2(4), 307-320.

Paulino, V. D. S. (2011). Influence of Risk on Innovation: Inertia Strategies in the Space Industry. Innovation, strategy, structure organizations, institutions, systems and regions. Copenhagen Business School, Denmark.

Redlinghuis, A. \& Rensleigh, C. (2010). Customer perceptions on Internet banking information protection. South African Journal of Innovation Management, 12(1), 1- 6.

Rogers, E. (1962). Diffusion of Innovations. New York, The Free Press.

Rogers, E. (1983). Diffusion of Innovations, 3rd Edition. New York, The Free Press.

Rogers, E. (1995). Diffusion of Innovations, 4th edition. New York, The Free Press.

Rogers, E. (2003). Diffusion of Innovations, 5th edition. New York, The Free Press.

Rugimbana, R. (1998). Values, Perceptions, and Consumer Preference Patterns for PersonalBanking Technologies in Australia and Malaysia, MacQuarie University. PhD (Marketing).

Sabi, H. M. (2014). Trends in the Diffusion of Internet Banking in the developing countries. Journal of Internet Banking and Commerce, 19(2), 1-31.

Shambare, R. (2012). Predicting consumer preference for Remote Banking Services in South Africa and Zimbabwe: The role of consumer perspections versus, personality variables. D.Tech Thesis: Tshwane University of Technology. SA.

Shiu, E., Hair, J., Bush, R. \& Ortinau, D. (2009). Marketing Research. Berkshire, McGraw-Hill.

Szmigin, I. T. D. \& Bourne, H. (1999). Electronic cash: a qualitative assessment of its adoption. International Journal of Bank Marketing, 17(4), 192-202.

World Wide Web. www.allbankingsolutions.

$\mathrm{Wu}$, J. (2005). Factors that influence the adoption of internet banking by South Africans in the Ethekweni metropolitan region. Dissertation of Master of Technology. Marketing Department, Durban Institute of Technology.

Yiu, C. S., Grant, K. \& Edgar, N. (2007). Factors affecting the adoption of Internet banking in Hong Kong: implication for the banking sector. International Journal of Information Management, 27(5), 336-351. 